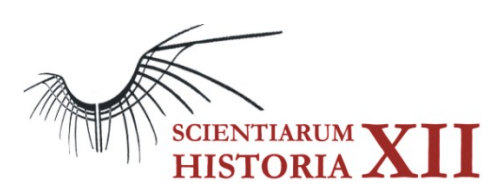

\title{
Artists and the sciences in the birth of Modern life
}

\section{Os artistas e a ciência no nascimento da vida moderna}

\author{
Franey Nogueira \\ Laboratórios de Métodos Avançados e Epistemologia/NCE/UFRJ \\ Programa de Pós-graduação em História das Ciências e das Técnicas e Epistemologia, \\ Universidade Federal do Rio de Janeiro \\ franeyn@yahoo.com
}

Recebido: 4/12/2019 Aceito: 8/12/2019 Publicado: 10/12/2019

\begin{abstract}
The time comprised in between the second half of the nineteenth century and the first half of the twentieth century presented a revolution in the sciences that shaped what came to be defined as Modern life. It influenced and affected all fields of knowledge and social relationships. In this article I analyze how some of the main inventions and discoveries of this period impacted artists and artistic movements in practical and philosophical ways and how they collaborated to the surge of abstraction in the visual arts.
\end{abstract}

Keywords: Art. Science. History.

Resumo. O período compreendido entre a segunda metade do século XIX e a primeira metade do século XX foi marcado por uma revolução nas ciências que moldou o que mais tarde seria definido como a vida moderna. Essa revolução influenciou e afetou todos os campos do conhecimento e das relações sociais. Neste artigo eu analiso como algumas das principais invenções e descobertas do periodo influenciaram artistas e movimentos, de maneira prática e filosófica, e como elas colaboraram para o surgimento da abstração nas artes visuais.

Palavras-chave: Arte. Ciência. História.

\section{Introduction}

In the young and recent field of research of Art and Neuroscience, many studies concentrate in the art produced in the Modern movements, which emerged in the beginning of the twentieth century and lasted for about five decades. Among the art 
styles presented in these studies there seems to be an apparent interest in abstract and Modern art. However, abstract art and Modernism were influenced by changes in the artistic interests and methods initiated by the Impressionists in the nineteenth century and the subsequent movements that came after them. In this article I describe in which context the Impressionist movement appeared and how the Science of the day, and the transformations it brought to society, influenced the artists as individuals and as a group, and its impact in the unfolding of Modernism and abstraction in painting.

\section{A scientific revolution}

The turn of the nineteenth century to the twentieth century was a time of significant changes in the western society when science and technology were evolving at a fast pace; its consequences were felt and observed in the urban structures of the biggest cities in Europe, changing social dynamics in many and unexpected ways.

The incredible quantity of discoveries and new theories delivered in the nineteenth century shows an eager for new knowledge and applications. Charles Darwin publishes "The Origin of Species" in 1859, presenting the concepts of "evolution" and "natural selection". Thomas Edison invents the lightbulb in 1879, and the phonograph, while Nikola Tesla introduces the induction motor. Around mid-century, the Laws of Thermodynamics are elaborated by William Thomson (Lord Kelvin) and Rudolf Clausius. In 1873 James Clerk Maxwell publishes the "Treatise on Electricity and Magnetism". Photography is invented in 1839 by Louis Daguerre and in 1886 Karl Benz sells the first commercial automobile. William Roentgen produced and detected the x-rays in 1895.

Artists benefited immensely on the new ways of locomotion, new and ready to use materials, the amplified access to information. By the end of the nineteenth century the invention of oil paint tubes brought a revolution to the painting practices, allowing artists to more easily carry them around, and it's fair to say that this fact alone influenced the routines of the Impressionists.

Following this pace, the first half of the twentieth century was likewise engaged with scientific and technological groundbreaking achievements and its impact was deeply felt on the artistic practices of the time. Werner Haftmann (1965) describes the synchronicity of artistic and scientific endeavors in his book "Painting in the Twentieth Century" as follows:

\footnotetext{
Dates seem to suggest that some kind of connection exists between Science and painting. The radical changes in painting took place between 1900 and 1910. Significant dates are: 1905 Fauvism; 1907 Cubism; 1910 the first abstract painting. A concordance of dates important in the history of Science runs thus: 1900 Planck's quantum theory; and Freud's Interpretation of Dreams; 1905 Einstein's special theory of relativity; 1908 Minkowski's mathematical formulation of the dimension of space-time. (HAFTMANN, 1965, p.8)
}

Revista Scientiarum Historia, 2019, 1(1): 72 
Haftmann also affirms that "twentieth-century painting cannot be considered in isolation from the sum of the ideas evolved in our century. It renders in visual terms the modes of thought and feeling in which modern man conceives of himself and the environment." (HAFTMANN, 1965, p.8) Although he is referring to movements from the beginning of the twentieth century, its origins trace back to the second half of the nineteenth century when the Impressionist painters first defied centuries of conventions.

The discoveries in Science inspired a new kind of representation and lead to a break with how painting and painting practices have been thought and taught for a long time. The first movement that defied the academic tradition was formed by the Impressionists and found in Monet its greatest icon. In Monet's work and career is possible to visualize a shift in representational modes; his paintings were, specially towards the end of his life, pointing to a future of abstraction where light and color were starting to be treated as independent elements, and even if not consolidated at his time, the seeds of abstraction appeared in that period, and blossomed later in the movements that followed. However, it was not a consciously science influenced movement, but a more intuition-based attitude that nonetheless felt absolutely in tune with its time and the possibilities it opened. The following group, the Post-Impressionists, reunited at Theo van Gogh's Gallery in Paris (Vincent van Gogh's brother), was more directly concerned with scientific discoveries and related publications and at least two of them, Georges Seurat and Paul Signac, were in direct contact with Chevreul of the Gobelins and his explanations of modern optics.

This new optical knowledge was the source and inspiration for a new painting technique created by the young Seurat, which would later be named Pointillism and was followed by many of his fellow artist friends. His work would also be highly influential on many artists and movements of his time and later, including Van Gogh, pushing his work into new and revolutionary grounds, and Marcel Duchamp, the father of conceptual art. Even Monet, who by the time Seurat appeared at the scene was already in an advanced career stage, felt compelled to further develop the Impressionist technique (LEWIS, 2007, p.238).

By the first decade of the twentieth century the Impressionists and Post-Impressionists works resulted in a new approach to the whole practice of painting, and it seems that while science brought into question the boundaries of our world, artists answered by questioning the boundaries of painting and its material and conceptual limitations. If the world was no longer constrained to the visible, what was then painting representing? Slowly, they moved from the representation of visible things to the representation of invisible things, following the expansions of a universe that was no longer comprised by our senses, now grounded in a wider and deeper comprehension of what constitutes man and the universe he inhabits. Thus, painting started to detach itself from direct visual relationships to objects and things and stated the canvas as an experimental space, a space where the painter would interpret how he was experiencing the world, and no longer what he was seeing in the world:

Revista Scientiarum Historia, 2019, 1(1): 72 




These changes occur in that system of relations between man and the world, heaven and earth, which constitutes temporal existence and determines our attitudes to reality; it may be called man's ground of reality. Changes take place within this system and are embodied in all spheres of intellectual life: in the shape of guiding theories of natural science, of philosophical reflections, of theological speculations and exegesis, of leading principles of psychology and so on. They are also visually reflected in the self-contained counter-images of works of art. (HAFTAMNN, 1965, p8)

Until that moment in history, science, as much as art, was delimited by the reach of our senses; our theories and concepts belonged to the close, physical reality, that our technologies and tools enabled us to grasp.

Positivist theory seemed to be at the base of the Impressionist's practices:

Their painting seemed to be given over to the rapid recording of transient, fleeting nature. The strong Positivist spirit of the age, moreover, was often evoked as the most crucial context for Impressionism's presumed in material, visual fact. As framed by August Comte and disseminated by his followers, the Positivist philosophy declared that only the tools of science - direct observation and empirical analysis - provided the means to credible knowledge. (LEWIS, 2007, p.238)

The Impressionist artists took "direct observation" to its limits, they would mostly paint outdoors, for extended periods of time, in order to register light and color sensations of one single motif, aiming to capture a specific time of the day. By concentrating on this specific task, they started to abandon faithful representation and began to render sensations instead of shapes, to what some critics responded with mockery and indignation. But science was also interested in the complexities of how we perceive:

In the nineteenth century the philosophers, physiologists, and physicists who talked about sensations as the ground of knowledge were inclined to explain the solid appearance of objects, their weight, all the other properties, by the sensory experience. That was also a program of other scientists who thought that they could reconstitute our knowledge of the world through analysis of sensations, innerbodily or so-called somatic sensations. All of these combine or are combined in reflection and by various spontaneous processes to yield us our ideas of things - thing is a term we use in order to designate a recurrent complex of sensations. This, at least, was the philosophy of many scientists and philosophers of the empiricist school, who also gave great weight to logical analysis of what was delivered by sensation. (SHAPIRO, 1999, p.96)

From the moment technologies and theories started to envision what was playing underneath the skin, or high above in the skies, we suddenly became aware of our bodies' physical limitations and thus of our senses as an instrument of accurate measurement and recording of the world around (and inside) of us. In terms of what our

Revista Scientiarum Historia, 2019, 1(1): 72 
direct perception of things were limited to, the new definition of what physical reality was constituted by became a matter of infinite possibilities living far beyond our eyes and hands, the revolutions in physics and science in general changed our deepest conceptions regarding how the world is truly constituted and we could no longer trust solely our senses in order to reach these intangible structures. The advances in microscopic imagery, for instance, helped deliver the mysteries of this veiled reality and "played a fundamental role in the reverence towards science". (SANTOS, 2015, p.5) Patterns and shapes arriving from the depths of cellular structures, unknown forms and structures, started to fuse with our previously visual knowledge. (SANTOS, 2015)

\title{
3. Abstraction in art and science
}

As we would soon testimony, the surge of abstraction in modern painting was apparently inevitable for it would become more representative of our understandings, our theories and of life itself. Painting could no longer be the same and attain itself to a faithful representation of the world once this vast and impalpable reality was discovered. Painting, as well as other artistic manifestations, would gradually loosen from representational function, searching truths beyond vision. The complexity of this transformation and its impact is described by Haftmann (1965):

\begin{abstract}
This new plane of reality was found to exist in the infinitely small and the infinitely large, in atoms, regarded as irreducible units in the structure of matter, and in the boundlessness of the universe. The first glimpse of this new reality was provided by Planck in his quantum theory (1900) and by Einstein in his theory of relativity (1905). Thus, it emerged at the beginning of our century at the frontiers of human consciousness. It brought about a mutation in our concept of reality, which passed, that is to say, to a new system of references in which the terms of the world of the senses were no longer valid. It could be grasped in terms of mathematics only and could in no way be rendered visible. The basic approach to its understanding leads away from the mechanistic way of thinking towards mathematical abstraction. (HAFTAMNN, 1965, p.9)
\end{abstract}

This revolution in the concepts rooting reality itself was a blast in artistic practices, the artist was no longer someone concerned with the learning of techniques specific to his faber or with the faithful reproduction of nature or with portrait commissions, from now on the artistic approach would be an investigation too, in some ways similar to those practiced in a lab. Rather than polishing acquired abilities, the artist is now required to experiment with everything that constituted the visual experience. In painting, particularly, it unfolded numerous movements and styles in a very short space of time and in less than one decade we left representation behind and embraced abstraction as our new future.

\section{The influence of new technologies}

There are other inventions and elements which influenced painters of the late nineteenth century that are worth of our attention.

Revista Scientiarum Historia, 2019, 1(1): 72 
The invention of photography in 1839 had an important role in many aspects concerning painting, and it is believed that the French painter Paul Delaroche, upon seeing for the first time a Daguerreotype, which was the first type of photograph, declared "From today, painting is dead." It was the realization that the functional role painters had in society had been clearly overcome. If, until that moment, painters were those responsible for registering visually the historical facts and its characters, and also common citizens, now this role would soon be replaced by the camera.

Photography stole from artists a function that irredeemably lost its place to the accuracy and readiness of the new technique, making painters lose a market that for long belonged to them. On the other hand, by leaving visual fidelity to the camera, they found themselves free to pursue other pictorial interests. As Mukand (2015, p.1) states: "painting did not die, only the limited assumptions of what painting was, or could be."

Thus, the way photography started to capture the world around them also had an impact aesthetics in general. Vincent van Gogh used for 6 years Cassagne's method and perspective frame on his open air sessions (IVES, 2005, p.9), he used the frame to correct and perfect the perspective on his paintings, but the purpose of his use seemed to be not only occupied with correcting perspectives: it was likewise a way of cutting out the landscape too. Photography showed the painters new ways to cut out the scene, it can be observed in paintings starting with the Impressionists where the photographic angles are clearly distinguishable. In addition, Melcher and Cavanagh (2010, p.369) state:

The influence of photography is not due simply to its potential to 'substitute' for painting: instead, photography also revealed the limitations of imitative optical depictions... The public could evaluate for the first time how heavily artists edited reality, when painting, to fit the expectations of the observers' eyes. In addition, many photographs do not look 'real' either. For example, the strange and unnatural way in which movement is often depicted by photography contrasts sharply with our perception of movement. The photograph raises the question: which is the real image: the one created by a camera or the one perceived in the mind's eye? (MELCHER; CAVANAGH, 2010)

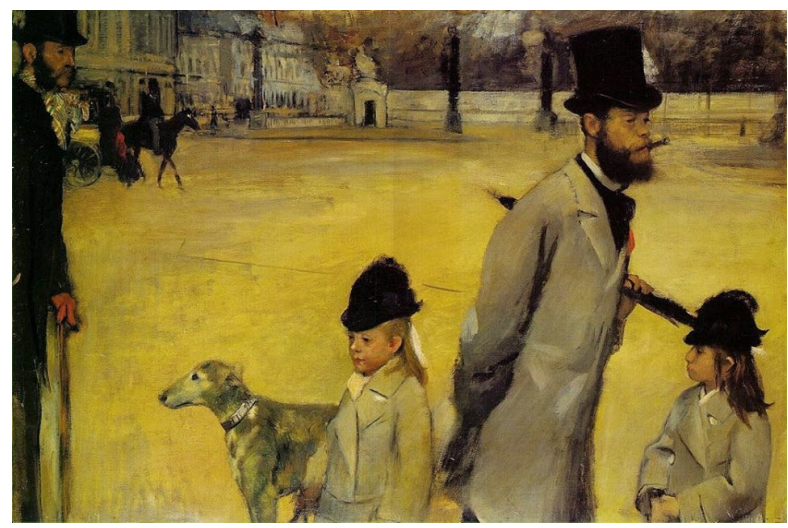

Revista Scientiarum Historia, 2019, 1(1): 72 
Figure 1. Place de LA Concorde by Edgar Degas, 1875

Source: wikiart.org

We can observe the repercussion of photography in the body of works of many Impressionist painters. Works like Place de la Concorde (1875) by Edgar Degas (figure 1), where the angle chosen to depict the scene and the focal points are worked in a new manner, is inferred from the photographic experience, Degas leaves empty the place that would commonly be the focus of attention and chooses an upper angle, as if the scene was observed from a moving carriage. (THOMPSON, 2000, p.196) Degas, amongst the Impressionist painters, was probably the most enthusiast user of photography as a tool for composition. Similar photographic angle choices can be found in Gustave Caillebotte's works such as "Paris Street, Rainy Day" (1877) or "Man in Balcony" (1880).

Cinema, the subsequent development from photography, also caught artists' interest and became influential in painting. The implication of the understanding of movement and the ability to play with intervals and cutting scenes revealed also a new comprehension of time. Cinema and photography, along with the invention of the phonograph that recorded voices, were a direct access to past events as never seen before in history. These inventions placed the human perception in a new frontier because it made possible to maintain, in a recorded manner, shape, movement and voice, providing an experience that could be subjected to indefinite repetition. The possibility of unrestrained access to the same event over and over again enabled an unprecedent type of perception, therefore modifying their memorization and observation too.

Another component surrounding the Impressionists and those who came after them was speed. The incorporation of trains and cars to the daily life, the last at the beginning of the twentieth century, and some years later the invention of the airplane, were all physical sensations that altered man's perception of time and space, resulting also in new optical experiences. Speed, or as Paul Virilio would later accurately call, acceleration, would become an integral element placed at the heart of human modern existence, altering our perception of life and demanding adjustments from our bodies.

The creation of cinema was too a form of speed incorporated to the modern habits, since it was the result of the acceleration of rapid picture change. Acceleration

Revista Scientiarum Historia, 2019, 1(1): 72 


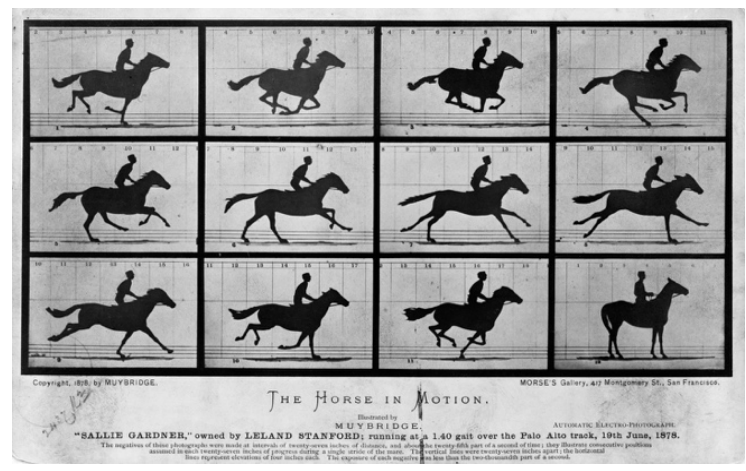

Figure 2. "The Horse in Motion" by Eadweard Muybridge, 1878

Source: commons.wikimedia.org

arrived also through bicycles, watches and by the use of telephone, which delivered news much faster and "affected newspaper reporting and modified the language of journalistic communication.” (KERN, 1983, p.115)

When observing the social surroundings of the Impressionist and Post-Impressionist painters there's a particular important invention that cannot go unnoticed: the incorporation of electric light to the cities and houses. Its implications in the everyday life were many. According to Schivelbusch (1995), by the end of nineteenth century the new form of illumination changed the color choices for interior decoration and also modified the dynamics of coexistence: "Electric light not only dissolved the center around which the family gathered; it also altered the whole appearance of the rooms it lit up, or rather, inundated with light." (SCHIVELBUSCH, 1995, p179) Electric light possessed a "hard, disembodied, abstract quality" (SCHIVELBUSCH, 1995, p.178) that rendered space and objects differently and called for adjustments. Another consequence of this transition was a "blurring division of day and night" (KERN, 1983, p.29) which began to alter the routine of cities and citizens.

\section{Conclusions}

The inventions and discoveries of the late nineteenth century and early twentieth century were quickly incorporated to the day-to-day lives, transforming the basic perceptions upon which the human bodies had functioned since the beginning of its existence. The profound reach of its consequences was felt in physical and philosophical grounds, altering man's perception of the world and of himself. The modern world is born in the nineteenth century, caught between wonderment and fear. The body is required to adapt to changes of modernity, and painting testifies, visually, to this new world and knowledge.

\section{Financiamento}

Revista Scientiarum Historia, 2019, 1(1): 72 
This work was carried out with the support of the Coordenação de Aperfeiçoamento de Pessoal de Nível Superior - Brazil (CAPES) - Financing Code 001.

\section{References}

HAFTMANN, W. Painting in the Twentieth Century Volume Two. New York: Praeger Publishers Inc., 1965.

IVES, C.F. Vincent van Gogh - The Drawings. New York: The Metropolitan Museum of Art, 2005

KERN, S. The Culture of Time and Space - 1880-1918. Cambridge, Massachusetts: Harvard University Press, 1983

LEWIS, M.T. Critical Readings in Impressionism and Post-Impressionism. Berkeley and Los Angeles, California: University of California Press 2007

MELCHER, D.; CAVANAGH, P. Pictorial Cues in Art and Visual. In: Art and the Senses. Oxford: Oxford University Press, 2010

MUKAND, N. The Many Lives of Painting: The Evolution of Contemporary Painting in the Face of Claims of "The Death of Painting". Munich: GRIN Publishing, 2015

SANTOS, S. Crossing borders: the path of photomicrography towards artistic recognition. MIDAS [Online], 5 | 2015, Online since 04 December 2015. Disponível em: https://journals.openedition.org/midas/875 Acesso em: 25 nov. 2019.

SCHIVELBUSCH, W. Disenchanted Night - The Industrialization of Light in the Nineteenth Century. Berkeley and Los Angeles, California: The University of California Press, 1995

SHAPIRO, M. Worldview in Painting - Art and Society. New York: George Braziller, 1999

THOMPSON, B. Impressionism - Origins, Practice, Reception. London: Thames \& Hudson, 2000. 